\title{
From dissidents to collaborators: the resurgence and demise of the Russian critical intelligentsia since 1985
}

\author{
Marina Peunova
}

Published online: 10 May 2008

(C) Springer Science+Business Media B.V. 2008

\begin{abstract}
This paper investigates the multifaceted universe of Russian intelligentsia and addresses the following, troubling, questions: What caused pro-democratic political dissent to weaken among the intelligentsia in the aftermath of perestrojka? Why has the young generation of Russian public intellectuals undergone a radical metamorphosis of their value system and plunged into political passivity and conformism? Freedom has historically been a prima facie value for the Russian liberal intelligentsia. By the mid-1990s, however, much of the intelligentsia came to be associated not with advocacy of individual liberty and human rights but with the failure of liberal democracy in Russia. This paper focuses on how the generation of the 1960s liberal intelligentsia, or shestidesjatniki, who played an active role during perestrojka, gave way to a generation of the "sons," who, characterized as Westernstyle intellectuals, became spin doctors and political technologists, replacing the original ideals and high moral stance of their predecessors with nihilistic nonchalance. It is argued that the demise of dissent in post-Soviet Russia derives from the younger generation of intellectuals' view of the attainment of political power by the generation of shestidesjatniki during perestrojka and the first El'tsin term as the latter's moral fall and abandonment of the intelligentsia's traditional role as an outside critic of the state.
\end{abstract}

Keywords Intelligentsia · Intellectuals · Dissent · Dissidents · Democracy · Russia · Perestrojka

"There is always something suspect about an intellectual on the winning side."

—Vaclav Havel, Czech writer and former Czech President

M. Peunova $(\bowtie)$

Department of International History and Politics, The Graduate Institute of International and Development Studies, 132, rue de Lausanne, Case postale 136, CH 1211 Geneva 21, Switzerland e-mail: peunova3@hei.unige.ch 
"We mean by the intelligentsia not, of course, the public that comes to the balls and the Nobleman's Assembly."

- Petr Struve, a philosopher and pre-revolutionary leader of Russian liberalism

"Freedom is one of the sorest subjects for the Russian intelligentsia."

- Iurii Lotman, the founder of structural semiotics in culturology

\section{Introduction}

This article rests on the disputable assumption that critical thinking conditions intellectuals to opposition and dissent. It is because of their antagonistic streak that intellectuals have been an inspirational force behind political resistance, including a great many revolutionary uprisings (Shils 1969, p. 33). While some intellectuals are conformist, such figures as Hannah Arendt, Vaclav Havel, Edward Said, and Noam Chomsky exemplify Jean-Paul Sartre's poignant definition of an intellectual as "someone who meddles in what does not concern him" (1965, p. 12). By 'meddling' in politics, public intellectuals often risk their careers, security, and even their lives. ${ }^{1}$

Just as it has shaped experiences of Western public intellectuals, civic opposition has also defined the Russian intelligentsia. Coterminous with the English term "public intellectuals" and the French intellectuels engagés, the Russian intelligentsia comprises a social group of those individuals who play a crucial role as critics of and a counterbalance to the state power (vlast'). The relationship between the intelligentsia and vlast' has always been crucial in Russian history, and peculiarities of this relationship have been, and still are, a reaction of the intelligentsia to the ambiguity and incomprehensibility of power and of its alienation from society. A Silver Age symbolist poet, Maksimilian Voloshin, poignantly portrayed the Russian intelligent as someone who is

Weak and persecuted, $[\ldots]$

A good soul, honest, spineless,

Imprinted, as a precise negative

Along the profile of the autocracy: a bump

In place of a fist, a hole in place of a bayonet,

A negation in place of an assertion,

Ideas, feelings-everything is to the contrary,

Everything is "through the prism of civic opposition.' ${ }^{2}$

The historical significance of the Russian intelligentsia has been defined by the intelligentsia's civic opposition. Aleksandr Solzhenitsyn famously coined the derogatory term "the smatterers" (obrazovantsy) to underline that one does not become an intelligent through education only but through adherence to high moral principles and a critical relation to authority (p. 125). The spirit of opposition, moral

\footnotetext{
1 Julien Benda cited in Kuzman (2002, p. 65).

2 The translation is mine.
} 
criticism of authority, and the belief that freedom is inextricably linked to the establishment of a just social order have been, since the mid-19th century, the main definitional characteristics of the Russian intelligentsia. This spirit drove the Russian Decembrists' 1825 rebellion at the Senate Square, a heroic act of selfsacrifice for the sake of the common good. The same spirit inspired the 1860s intelligentsia. The spirit of dissent resurfaced a century later, during Khrushchev's thaw in the ideas and practices of shestidesjatniki, the generation of liberal intelligentsia of the 1960s. Two decades later, Mikhail Gorbachev's reforms signaled the "second thaw" that ultimately melted the Soviet state's authoritarian structure and created an unprecedented window of opportunity for the intelligentsia finally to assume a leading part in sociopolitical events and to become "heroes of a new, individualist era" (Gasparov 1999, pp. 5-6). During this time, shestidesjatniki became moral authorities, and certain dissidents, most notably the formerly persecuted physicist Andrei' Sakharov as well as the lawyer and champion of human rights, Sergej Kovalev, acquired political prominence.

By the mid-1990s, however, much of the intelligentsia came to be associated not with its traditional role as critics of government and defenders of freedom, human rights, and the rule of law but with power, corruption, and the failure of liberal democracy in Russia, as many intelligenty became servile to the state while others plunged into political apathy. As the older generation of shestidesjatniki, the fathers, were leaving the public scene, their sons, the younger generation of intellectuals, abandoned liberal democratic beliefs. In doing so, they replaced advocacy for individual liberty and rights with nationalism built upon state security, sovereignty, and national interest, and engaged in the construction of discourses on "Fortress Russia" (Iur'ev 2004) and "nostalgic retrospective conservatism." (Kolesnikov 2004).

A number of theorists explain the demise of opposition and dissent as well as the ideational shift within the ranks of the Russian intelligentsia by the universal collapse of critical thinking and the triumph of political conformism that has been most notably identified by such illustrious public intellectuals as Michel Foucault, Herbert Marcuse, and Noam Chomsky, among others. ${ }^{3}$ The social havoc, disintegration of the state, and overall spiritual and ideological crisis that overshadowed Russia during the Boris El'tsin years has also undoubtedly contributed to the downfall of intellectualism in Russia where, since the mid1990s, the disillusionment with liberal democracy - a concept which was to be the panacea for Russia's societal ailments-has supplanted initial enthusiasm. I do not presume to refute the validity of these arguments; rather, my attempt is to supplement these explanations with a more nuanced dimension based on generational dynamics during the 20 years since the inception of perestrojka. I argue that the transmutation of post-Soviet political dissent in Russia into passive compliance with the decisions taken by the government stem from the younger intellectuals' negative perception of the shestidesjatniki's role during perestrojka and the first El'tsin term. As dissidents among shestidesjatniki acquired political leverage and moved to the other side of the line that traditionally separated the intelligentsia from

\footnotetext{
${ }^{3}$ On the waning role of intellectuals in the public sphere, see Furedi (2004).
} 
the state, the younger generation of intellectuals saw this "going to the state" (khozhdenie vo vlast') as an indication of the shestidesjatniki's corruption by power. This move delegitimized the intelligentsia and dealt a final blow to the concept of the intelligentsia as a dissenting critic of the regime. I start by briefly revisiting the generation of shestidesjatniki. I then examine the role of shestidesjatniki, particularly of dissidents among them, during perestrojka. I finally elucidate the paradigm shift from liberal democracy to conservatism and from dissent to consent among the younger generation of intellectuals in the aftermath of perestrojka.

\section{Shestidesjatniki revisited: a glorious generation}

Perhaps the only well-defined Soviet generation, shestidesjatniki defy clear definition. According to Andrei' Nemzer, "Nobody could really tell who they are; the word was becoming a symbol, a swearword, a compliment-anything but a term." 4 In my understanding of shestidesiatnichestvo, I follow the Mannheimian tradition of conceptualizing a generation not in a biological but a sociological sense as an "agent of social change" that unites people who share similar values and behavioral patterns (Mannheim [1927] 1952; Laufer and Bengston 1974; Voronkov 2005). Thus, while most shestidesjatniki were the segment of pro-Western intelligentsia whose youth coincided with Khrushchev's Thaw, the group is primarily defined not by age but by their belief system. The generation of the $1960 \mathrm{~s}$ is often compared to the Decembrists and to the generation of the 1860 s in that they all resisted lies and violence and engaged in peaceful civic protest while fearlessly upholding their beliefs and not bowing to a repressive regime. The shestidesjatniki of the 1960s combined their admiration of the West with devotion to communism. They were supportive of Khrushchev's reforms but called for more radical changes, some of them in direct confrontation with the state. In this sense, they were nonconformists who hoped that the monopoly of the Communist Party would one day end.

Soviet dissent arose out of the spirit of shestidesiatnichestvo. The children of the thaw, shestidesjatniki embodied the dissident movement initiated following the 20th Congress of the Communist Party (1956) and in response to the suppression of Hungarian and Polish uprisings during the same year. The history of the Soviet dissident movement began with arrests in 1957 of groups of oppositionist members of the intelligentsia. The movement continued until the late 1970s-early 1980s when it was violently suppressed, its members persecuted and placed in mental institutions, and others forced into exile. Thus, while shestidesiatnichestvo ended with the Prague Spring in 1968, we may speak of the 30 years of political protest (1956-1985) prior to perestrojka as one continuous period.

\section{Intelligentsia's gilded age: Shestidesjatniki during perestrojka}

During perestrojka, in their steadfast support of democratization, the intelligentsia was stimulated by the slogans of "freedom," "social justice," and the "rule of law."

\footnotetext{
4 Andrei Nemzer cited in Voronkov (2005, p. 173).
} 
These principles were already articulated by the pre-revolutionary intelligentsia but became catchwords during the 1960s. The ideational roots of the Gorbachev-era reforms are embedded in the spirit of shestidesiatnichestvo and in the 30 years of Soviet dissident movement including human rights activism which, by the beginning of perestrojka, had reached its peak and waned. But this fiasco of underground dissent only inspired further radicalization and politicization of the younger generation of intellectuals who called for extreme societal transformation. ${ }^{5}$ Thus, according to Tatiana Zaslavskaia, it was not just shestidesjatniki who supported perestrojka but also the younger generation who were in their 20 s and 30 s. $^{6}$ Thus, sons and fathers alike united under the banner of perestrojka as, "living beneath unthinkable tyrannical pressure, the intelligentsia built up within itself a colossal charge of negative energy[,] ...an unbridled thirst for a universal restructuring." 7

It was democracy understood as respect for individual liberties, freedom of press, and the rule of law that the intelligentsia called for during perestrojka. Differing from the dissident calls for transformation, official perestrojka nevertheless opened the gates for the critical intelligentsia to eventually take the driver's seat in politics. Many shestidesjatniki, some of them former dissidents, played an active role during perestrojka. In 1986 Gorbachev welcomed the return of Andrei Sakharov from Gorky, where this renowned scientist spent time in exile. Sakharov's release denoted Gorbachev's desire to establish cooperation with the intelligentsia and the educated élites and demarcated the beginning of the intelligentsia's political awakening (Garcelon 1997, p. 51). In 1987, during the Plenary Party Session, articles 70 (anti-Soviet agitation) and 190 (collaboration with anti-Soviet agitation) of the Criminal Code of the Russian Soviet Federative Socialist Republic were amended. A subsequent amnesty led to the rehabilitation of other political prisoners; upon their return, many of them, including Sakharov, joined the democratic movement.

In 1988 the Democratic Union was formed as the first political opposition protoparty. In its founding declaration the DemSoyuz leaders postulated that "uniting us all is an adherence to the ideals of democracy, which for us is not a slogan, but the form and the meaning of a state system based on political, economic, and moral pluralism, on a multi-party system, legal opposition, a free press, and independent trade unions." 8 In its outright criticism of the socialist system and official perestrojka's stance of the return to true Leninism, the DemSoyuz called the Soviet Union a totalitarian state. Its members pushed for national self-determination for the republics and the withdrawal of Soviet troops from Afghanistan. In opposition to all forms of totalitarianism, these intellectuals wanted to construct a "liberal model of capitalism" in Russia, which would be based on individualism and private property. ${ }^{9}$

\footnotetext{
5 Kagarlitky cited in Petro (1991, p. 111).

${ }^{6}$ See Zaslavskaia (1988).

7 Vladimir Pastukhov, cited in Kagarlitsky (2002, p. 51).

8 The Democratic Union Program, Archive of the Democratic Union, 1989, [http://www.ds.ru/ oldprog.htm].

9 Declaration of the Democratic Union of Russia, December 19, 1993, [ http://www.ds.ru/ust.htm].
} 
The intelligentsia found its main political tribune in the Congress of People's Deputies. ${ }^{10}$ The Congress met twice a year in order to pass legislation and to advise the government. Its meetings were televised, which allowed the country to follow debates, thus creating unprecedented pluralistic opportunities for expressing dissenting opinions and criticizing the official Communist Party line (Fish 1995, p. 35). It was through the Congress that the intelligentsia began to acquire political power and gained an opportunity to work at weakening the regime from within. Many prominent intellectuals became deputies, among them theater directors Oleg Efremov and Mark Zakharov, the writers Viktor Astaf'ev, Valentin Rasputin, Vassil' Bykov, and the editor of Novyi Mir, Sergei Zalygin, and the physicists Andrej Sakharov and Roal'd Sagdeev. Pavel Bunich, Nikolaj Shmelev, Dmitrij Likhachev, Chingiz Ajtmatov, Evgenij Evtushenko, Fedor Burlatskij, Tatjana Zaslavskaja, Jurij Karjakin, and many others were also members. The intelligentsia thus came into direct contact with political decision makers and some became decision makers in their own right. When it became clear that the Communists still outnumbered the democratic forces within the Congress, 250 pro-democratic deputies united in a revolutionary fraction of the "Interregional Deputies Group," with Boris El'tsin, Jurij Afanas'ev, Gavriil Popov, and Estonian Academician Victor Palm as its Chairs. The pact between El'tsin, a representative of the party nomenklatura, and the liberal intelligentsia was concluded in the Moskovskii Klub Intelligentsii and the Moskovskoe Ob'edinenie Izbiratelei (MOI). This conglomeration called for the abandonment of socialism, further market reforms, and the Russian Federation's (RF) sovereignty from the USSR.

In March 1990, Article 6 (the leading role of the Communist Party) was removed from the Constitution, and it was now possible to organize political parties that would challenge the Communists. The founding in 1990 of the DemRossia (Democratic Russia Movement) became the watershed event that led to the cementing of perestrojka from above and the metamorphosis of the intelligentsia into a new political power. Under its umbrella this proto-party united informal groups, associations, and unions, as well as reform-oriented individuals from the Communist Party. The Party nominated El'tsin for President of the RF in 1991 and coordinated his campaign. While DemRossia was fractured by internal conflict, at the same time, it was the most significant pro-democratic coalition of the early 1990s in Russia.

Whereas during the "first act" of perestrojka (1985-1989) Gorbachev relied on the intelligentsia's support in his battle with conservatives within the Communist Party, the Soviet leader changed his strategy as the situation began to spin out of his control. Thus, by 1989 he firmly decided to curb the increasingly activist democratic opposition led by the intelligentsia, initiating a new phase of reaction during perestrojka's "second act" (1989-1991). However, far from putting an end to the intelligentsia's radical aspirations, this policy only propelled its members towards adopting ever more extreme objectives. The radicalization of the democratic movement during the last years of perestrojka led to the unification of formerly

\footnotetext{
10 The first contested election in many years to the Congress of People's Deputies was an event of a truly historical significance. See Sheinis (2003, pp. 31-44).
} 
divergent groups and to an open confrontation thereof with the Communist establishment, a confrontation that escalated towards a revolution in August 1991. The dramatic events of the Fall of 1991 ended in a defeat of the state and the Communist Party and the election of the intelligentsia's protégé, El'ltsin, as the first president of the RF. The liberal intelligentsia's crusade against its Communist nemesis ended in the de-legitimization of the Communist Party and the introduction of full-scale liberalization reforms.

Perestrojka thus ended with a true victory of the pro-democratic intelligentsia. While Gorbachev never envisioned bringing about a complete abrogation of Communism and never ventured further than a return to Leninist principles, the intelligentsia delegitimized not only Stalinism but the very core of the Soviet ideology embedded in Leninist thought, and united in support of pro-Western liberalism. It sufficed for the state to half-open the valve for the former dissidents to push further, and, in the person of El'sin, to join forces finally with the state. Thus, from principled non-acceptance of the regime the former dissidents turned to collaboration with it. The intelligentsia descended from its high moral horse and entered cold politics.

\section{Krizis zhanra: the intelligentsia's support for El'tsin}

The events of the 1991 putsch led to the integration of former dissidents into the system, as those who fought on the barricades (some of them literally) joined El'tsin's government as ministers and advisers, thereby no longer representing a resistance force but, rather, the political élite. El'tsin surrounded himself by young liberal economists such as Egor Gajdar, Anatolij Chubajs, and Grigorij Javlinskij, while many former dissidents found a niche within the radius of the political sun and became celebrity figures, such as Sergej Kovalev, a pravozashchitnik (human rights activist) who assumed a position as Ombudsman of Human Rights.

While the 1991 revolution marked the highest point of the intelligentsia's romance with the state, the revolution of 1993 marked the solidification of the affair's end. The 1993 smuta (time of troubles) was characterized by the crisis of semi-presidentialism and a diarchy between the Kremlin and the parliament. ${ }^{11}$ Although the intelligentsia stood by El'tsin in both cases, the wholehearted support of 1991 gave way, by 1993, to a backing mired in suspicion and distrust. During these years, the intelligentsia found itself in an ambiguous position as collaboration with the state entailed standing by the undemocratic measures to which the government resorted in order to avert anarchy and to expedite the coming of the bright new capitalist future. Within the span of these few years, the intelligentsia's elation was replaced by a sense of betrayal: immediately following the defeat of the State Committee on National Emergency $(G K C h P)$ in August 1991 El'tsin demonstrated his repressive streak by first banning the Communist Party, closing a number of pro-Communist publications, and transferring ownership of the Party's

\footnotetext{
${ }_{11}$ For an excellent analysis of this crisis, see Huskey (2001).
} 
buildings to privileged democrats. ${ }^{12}$ Moreover, the first Russian president secured the upper hand over the Supreme Soviet, disregarded the Constitution, and used his powers to initiate, in the winter of 1992, market-oriented reforms by Presidential decree. The parliament was dissolved in September 1993, and a new "unconstitutional" Constitution, which many critical intellectuals believed to be a far cry from what they had hoped to achieve for their country, was introduced. Thus, far from living up to the intelligentsia's aspirations, El'tsin proved to be an authoritarian leader dressed in democratic clothes.

Despite certain signs of doubt, the intelligentsia still united behind El'tsin during the White House insurgency in October 1993 and the adoption of the new Constitution. In an attempt at self justification, Afanas'ev wrote that " $[\mathrm{t}] \mathrm{he}$ battle was not between 'good' and 'very good', but between 'bad' and 'very bad" (Afanas'ev 2005, p. 49). Like many fellow reformers, the historian felt consternation when the Kremlin used force against the insurgents at the White House; he accused El'tsin's ideologues of mobilizing public opinion, and criticized the intelligentsia for believing that there was no other way but to curtail this rebellion forcefully. In his article entitled "Bloody October" Gavriil Popov characterized these events as follows: "In Russia temples were built on blood: for the sake of eternal memory and in order to endure. The new Constitution of Russia was likewise written with the people's blood. This blood was not for nothing: the people got nothing, but out of this blood a modern Russian democracy was born." 13

If the dissolution of Parliament in October 1993 and the new Constitution were the first red lights that sealed the period of hope for the creation of an open democratic society, the beginning of the first Chechen War in December 1994 was the final blow to the intelligentsia's belief that it had leverage on the government: while some intellectuals were critical of the war, it, nevertheless, continued. Kovalev, the Human Rights Commissioner, was one of the few intellectuals actively engaged in advocacy against the war as he documented the atrocities of the Russian army and human rights violations from Grozny. Such former Soviet dissidents as Aleksandr Lavut, Arsenii Roginskii, Aleksandr Podrabinek, Sakharov's wife Elena Bonner, as well as Memorial activists, supported Kovalev's cause (Horvath 2005, pp. 138-149). However, their efforts to put an end to the campaign were futile as liberal journalist Masha Gessen has noted (Gessen 1997). Kovalev and his supporters were too few to bring forward a change, as their voices drowned in the overall silence that descended upon the fragmented ranks of disenchanted intelligentsia.

While initially opposed to the war, the majority of the intelligentsia came to view the Russian campaign in Chechnya not unlike it was officially portrayed by El'tsin's government: a "restoration of the constitutional order" and the rightful fight against organized crime. Chechens were seen not as freedom fighters but bandits and

\footnotetext{
12 Buildings belonging to the CPSU became property of the new democratic government. For example, the buildings of the Vysshaia Partiinaia Shkola were given to the Russian State University for the Humanities where one of the reformers, Iurii Afanas'ev, was the dean, and a palace of the Vysshaia Partiinaya Shkola was given to the International University of Gavriil Popov, another radical democrat.

13 Popov (2003). The article appeared in commemoration of a 10-year anniversary of the shelling of the White House.
} 
Muslim fundamentalists represented a security threat for Russia. This situation was further helped by the Chechen leader Dzhokhar Dudaev himself, as he often referred to the 'Islamic threat' in order to prevent a Russian attack in 1994 (Lieven 1999, p. 364). Needless to say, Dudaev played on the Russian fear of Muslim fundamentalism by hinting that certain Islamic states are interested in the fate of their Muslim brethren in Chechnya and that foreign combatants were coming to the region in order to participate in a holy war against Russian infidels (German 2003). The First Chechen War thus further fueled Russian patriotism and hammered the last nail in the coffin of human rights activism. Kovalev's stance on Chechnya cost him his position as an Ombudsman of Human Righs as he, along with like-minded members of the intelligentsia, was accused of anti-Russian propaganda and lack of patriotism.

The destabilizing upheavals that followed perestrojka such as the dissolution of the USSR, nationalist strife, economic hardship, the rise of crime and the de-valuing of human life, led the intelligentsia to renounce their support for reform while muting their reaction to the first Chechen War. As many former liberals joined the conservative camp, human rights, as a concept, lost its appeal in the eyes of the intelligentsia in favor of the principles of state security, sovereignty, and the inviolability of state borders.

The intelligentsia adapted its usual state of mind-that of self-denunciation, as it felt powerless to bring an end to the conflict. During the 1996 election, for lack of a better alternative the liberal intelligentsia grudgingly supported El'tsin's nomination for a second term. The intelligentsia's frustration at that time was depicted by Sergej Zalygin: "I do not know whether to elect Sergej Kovalev as president, or appeal to the intelligentsia to go to the people, or to engage in farming, teaching, or to become a lathe operator, or to study the Bible, or to reason according to Chekhov" (Zalygin 1995).

Perestrojka and the first half of the 1990s demonstrated that, like a moth coming too close to light, the intelligentsia was blinded by too direct an exposure to power. The period of the intelligentsia's active political involvement did not last for long, and many of its most illustrious members were affected to the core, became disillusioned or morally corrupted. A resolute democrat, El'dar Rjazanov, proclaimed with disgust: "It is too bad that the [Communist Party of the Soviet Union] was taken away from our democrats. They immediately turned into marauders" (Rjazanov 1992). Sergej Stankevich, for instance, was accused of money laundering and emigrated to France. Gavriil Popov became an authoritarian Moscow Mayor. Professor Ruslan Khasbulatov, the Chairman of the Supreme Soviet of the RF, embodied the corruption of the intelligentsia by moving into Leonid Brezhnev's former apartment on prestigious Kutuzovskij Prospect. Having lost their high ethical stance, these members of the political élite were no longer perceived to be the intelligentsia, and the definition of the group itself became the subject of intense self-scrutiny.

Far from bolstering the intelligentsia's new power status, this experience of khozhdenie vo vlast' led to the intelligentsia's identity crisis, and the initial jubilation was supplanted by lingering apprehension. The period of 1991-1995 can be considered the "intelligentovedcheskoe pyatilietie" (5 years of most intense 
study of the intelligentsia): some 15 conferences on the subject of the group's role in society and its relation with the state took place around the country. ${ }^{14} \mathrm{~A}$ wave of articles critical of the liberal intelligentsia appeared, ranging from criticism by communists and patriots to self-condemnation by members of the democratic intelligentsia itself. ${ }^{15}$ Among these "sorrows of the old intelligentsia" were proclamations of the intelligentsia's death and of intelligenty's reincarnation as western-type intellectuals (Gudkov 1992). The verdict that the intelligentsia was now non-existent appeared on the pages of the major journal, Znamja, as if to end the two centuries of popularity of "thick journals." Shestidesiatnik Granin thus summed up the sorry state of the intelligentsia in the new post-perestrojka world:

These stormy processes in the country are changing the destiny of the Russian intelligentsia. In this new, pragmatic, rational world, less and less space remains for the previous spiritual communion, with all the charm of the heated interest in the new books, the theater premiers, the exhibits. We lived for art. The "thick" literary journals had hundreds of thousands of subscribers. The monthly journals, Novyj mir and Znamja, each had circulations of more than a million copies. Today their circulations are down to under fifty thousand, but not only because the price has gone up. People just do not have time to read. And they do not feel like reading. The intelligentsia is finding a different base. People are going into business. The dissident movement has run out of steam. The intellectual opposition today has no program. ... The old Russian intelligentsia is disappearing and may grow extinct" (Granin 1995, p. 75).

As throughout Russian history, when the country found itself at a crossroads, the intelligentsia was expected during the 1990s to show the way and to say the "last word." When proved unable to produce miracles, the intelligentsia felt subject to disapproving scrutiny by both internal and external critics. Each phase of Russian history concluded with the evaluation of the intelligentsia's actions by the intelligentsia itself in works including Vekhi, Iz glubiny, and Iz-pod glyb. During the 1990s, many self-flagellating accounts by members of the intelligentsia made reference to the authors of Vekhi.

With the liberal intelligentsia's help, socialism was completely discredited during perestrojka, and equality and egalitarianism came to be associated with the failed experience of uravnilovka (levelling). This attitude is evident in the emotional reply of Ales' Adamovic, a writer and one of the maitres of perestrojka to Western intellectuals of the left:

"[F]ight for the cause yourself, that will be plenty! Trying to talk us into continuing the building of communism, socialism with a 'human face', is the same as trying to convince the residents of Chernobyl that 'clean' and 'safe' nuclear power is possible" (Adamovic 1995, p. 102).

\footnotetext{
14 See Memetov (1996).

15 For but a few out of a multitude of articles that resulted from these sorrows of the intelligentsia see, for instance, Tret' iakov (1997); Nikolaeva (1997); Granin (1997).
} 
At the same time, while there was no way back to the socialist past, the capitalist future and the prospects of successful liberalization seemed gloomier. Neoliberalism à la russe dealt a serious blow to the majority of the intelligentsia as, in Boris Kagarlitsky's words, “[t]here was no place in the conception of the neo-liberal economy for an intelligentsia of the Russian type" (Kagarlitsky 2002, p. 52). Contrary to some enthusiastic accounts, the majority of the intelligentsia did not miraculously metamorphose into a middle class: $44 \%$ of the intelligentsia found themselves below the poverty level and $7 \%$ below the level of extreme poverty (Sabov 2001, p. 5). Many intelligenty failed to adapt to the market economy, and more and more became nostalgic for the Soviet era. Partially in light of this economic hardship, the intelligentsia no longer had time for thinking about social justice and the fate of the people as it became engaged in "a battle of survival on a biological level" (Smolina 2000, p. 146). For those members of the intelligentsia who became involved in politics, "[t]he place of sincere sympathy for the authorities ... was quickly taken by material dependence on them" (p. 120). Constant preoccupation with byt (everyday drudgery), and the lack of money undoubtedly contributed to a spiritual crisis of the intelligentsia. While many continued their intellectual occupations and plunged into poverty, others went into business. ${ }^{16}$ Still many others emigrated creating a massive brain drain and provoking criticism from those who stayed behind.

As a result of this new climate, the whole value system of even those intellectuals who succeeded to adapt to the laws of the market had changed. It is no longer considered praiseworthy to be a gadfly and a critic of an almighty regime that spits into the wind. While the old-style intelligenty, even the well-to-do among them, were above meshchanstvo (philistinism) and materialism, the new well-off Russian intellectuals evoke bobos, the bohemian-bourgeoisie in the West, as they evaluate their worth and status in material terms and in new cars, luxury apartments, and shopping trips abroad.

On the ideational plane, the divide between liberalism and the Red-Brown coalition of communists and patriots was bridged during the El'tsin era to give birth to eclectic proto-ideologies. In 1993, the prominent historian Aleksandr Akhiezer advocated a conservative, or pochvennyi (grass-roots), liberalism (1993, pp. 12-21). Many other intellectuals called for a "conservative turn" to traditional values. Thus, Sousanna Matveeva deemed "classical" liberalism to be an impossibility in Russia with its particular history and culture. Similarly to Akhiezer, Matveeva saw the value of conservative liberalism in that "it tries to work out a liberal paradigm and its basic ideas and principles based on grassroots material" (1993, pp. 5-10). Matveeva proclaimed conservative liberalism "a real and a growing tendency that has cultural and social roots" (p. 13). In 1995 Inoe, a watershed four-volume anthology of sharp criticism of liberalism, was published. This volume later served as a foundation for the creation of the pro-nationalistic Russkij zhurnal. Inoe presented an alternative to the ideas of the perestrojka era as it questioned the

\footnotetext{
${ }^{16}$ Many scientists went into business and utilized their know-how in the private sector. Thus, once unpromising biologist Mikhail Iur'ev abandoned genetics to become an entrepreneur and one of the richest men in Russia. Iur'ev is the author of a notorious article "Fortress Russia" where he advocates complete isolationism (autarchy) of Russia and warring anti-westernism. Iur'ev ([2004] 2005).
} 
developments of the past decade and proposed original ways out of the imbroglio. While the volume united under its cover an unexpected array of authors with opposing views, ranging from pro-western to nationalist, ${ }^{17}$ the compilation signified the end of the intelligentsia's support for liberalism.

As the events of the roaring 1990s unraveled, the intelligentsia eventually lost its fleeting political leverage, and some of its members remained servants of an increasingly autocratic regime while others became indifferent to politics altogether by the end of the decade. Although the more honest among the intelligentsia retired from the political stage, others continued their collaboration with the regime, thus giving up their group identity and making the concept of the intelligentsia more nebulous than ever.

\section{Intelligentsia and pustota}

Before turning to the Putin era, I shall first take a literary detour into the work of Viktor Erofeev and Viktor Pelevin. Erofeev has captured the essence of the relationship between the intelligentsia and the state under Putin:

"I ... dreamed of Putin. I asked him why the Russian intelligentsia disappeared from the television screens. ...It pained him that the Russian intelligentsia had disappeared. ...Putin is a tsar of the Russian dream. This is the main reason for his success. He exists for Russians on the level of the subconscious. He promises to each what each needs the most. ...he...was playing the Void (pustota) that each of us could fill with one's feelings. The Void of Putin does not believe in the efficacy of words and slogans. It does not tolerate any resistance. It is an all-consuming, self-sufficient hole" (2004).

The author of the famous Chapaev and Pustota (Chapaev and the Void), Pelevin (2003) made a peculiar allusion to the novel Melkii bes (Petty Demon) by the Symbolist author Fedor Sologub. The main character in Sologub's work is driven to madness and is haunted by an omnipresent petty demon, who exists only in his imagination. In one of his interviews, Pelevin made a reference to the Sologubian imaginary character:

"In Russia, nothing ever changes. Something else happens-the same guest constantly comes to our house, a petty demon, who dresses as a commissar, then as a traveling salesman, then as a bandit, then as an FSB agent. The main goal of this petty demon is to trick you, to make you believe that everything changed, when in fact it is only his dress that has changed" (2003).

One does not need much imagination to guess who Pelevin alluded to as Russia's current melkii bes. State power has always represented in Russia the omnipresent Void. And yet, something has changed. During the Soviet times power worked through language as the population, in Stephen Kotkin's terms, identified with the

\footnotetext{
17 Contributing authors to Inoe were Sergei Kurginian, Andrei Fadin, Vadim Tsymburskii, Mikhail Gefter, Teodor Shanin, Aleksandr Panarin, Simon Kordonskii, Vladimir Makhnach, and Petr Shedrovitskii. See Sergei Chernyshev, ed., Inoe, Moskva, 1995.
} 
regime through "speaking Bolshevik" (Kotkin 1995, pp. 198-237, pp. 488-515). Like the rest of the population, the intelligentsia engaged in doublespeak through which they succeeded in their careers and, during Stalinism, survived. What is more, the intelligentsia leaped from official Soviet discourse, which they engaged in as constructors of Soviet social reality, to unofficial — dissident—kitchen talk in which they fulfilled the group's task as a critic of that very society which they helped to construct. With Putin's ascendance to power, the official and unofficial discourses have come to represent one and the same as today's intellectual no longer differentiates between official and unofficial discourses. Free from an internal conflict, today's intellectual happily works for Gazprom and "speaks Gazprom."

The figure of Putin is central to understanding the most recent period in the history of the Russian intelligentsia. In 2000, journalist Leonid Poliakov wrote an article under the title "Liberal'nyj konservator" ("Liberal Conservative") where he accurately noted the enigmatic and unpredictable nature of the Kremlin's ruler and compared him to a "white sheet of paper" and a "black box" (p. 20). On the one hand, upon his accession to power, Putin proclaimed that he is against the restoration of any official ideology as "in democratic Russia there should be no coercive public consensus." ${ }^{18}$ On the other, he reopened the El'tsin-era debate about the new national idea. By implicitly re-instating ideology as an important component of politics, Putin thus initiated an auction for new ideas and the coming of a new epoch for the post-Soviet intelligentsia and for Russia. This auction is, however, not a marketplace, as the process is controlled by the state thus stamping out free debate. In other words, Putin's regime collects from intellectuals a grab bag of concepts which are then molded into an eclectic new ideology according to the regime's needs.

During Putin's first term, patriotism and liberalism solidified into a new ideational trend propagated by the state leader himself and imitated by a majority of public intellectuals. Liberal conservatism transfused into a discourse on "sovereign democracy," the term coined by one of the chief state ideologues, Vladislav Surkov. ${ }^{19}$ Based on the premise that Russia is pursuing its own distinct path of development under the guidance of the supreme power of the state, the concept of sovereign democracy is being molded into a solid edifice of semi-official state ideology.

In his widely read Generation $P$ on the life of copywriters in the advertisement industry, Pelevin implicitly accounts for the transformation of the intelligentsia into polittekhnologi. In a conversation between two copy writers, one sighs that:

"You know, you and I are ideological workers, if you haven't realized it yet. Propagandists and agitators. For that matter, I used to work in ideology before, too, on the level of the Komsomol Central Committee. All the others are bankers now, I'm the only one left...So I tell you, I didn't need any reconstructing. Before I believed that 'the individual is nothing, the collective is everything.' Now I believe that 'the image is nothing, the craving is

\footnotetext{
${ }^{18}$ Vladimir Putin, 1999 policy manifesto "Russia at the Turn of the Millenium," January 1, 2000, [http:// www.pravitelstvo.gov.ru].

${ }^{19}$ Surkov (2006).
} 
everything.' Agitation and propaganda will never die. The only thing that changes is the words" (1999, p. 139).

Under Putin's regime, the intelligentsia have become a mouthpiece of liberal conservatism and sovereign democracy. For a prominent intellectual, Aleksandr Neklessa, this intelligentsia no longer exists and has given way to ljudi vozdukha (people of air), or the new intellectual class that "now creates not novels nor poetry, but high geostrategic and economic technologies" (2005). As if a character in Pelevin's novel, Putin's ideological right hand and a former dissident, Gleb Pavlovskij avers that his goal is to produce "a symbolic image of a reality that needed to exist, but which in the short term could not be realized in practice." ${ }^{20}$ The new intellectuals cater to the needs of the current regime and blend with other social groups in entrusting in Putin their hopes for the end of chaos of the previous decade.

The majority of intellectuals in today's Russia perceive Putin to be the savior from the chaos of the El'tsin years and an antidote to the anarchy of the 1990s. Many intellectuals would subscribe to Roy Medvedev's (2004) praise for Putin's qualities in the historian's biography of the Russian leader: “...it is precisely such a leader that was needed in our times, needed by the course of events, by the people of Russia” (p. 8). Since the early 1990s, authors including such early proponents of soft authoritarianism as Andranik Migranjan, Vitalij Najshul, Sergej Kurginjan, and Aleksandr Panarin, as well as other contributors to Inoe, personified the resurrection of a conservative wing within liberalism. ${ }^{21}$ Some of these intellectual figures who were active during the El'tsin era formed the bulwark of the conservative drift during Putin's administration (Mezhuev 2004). A former liberal and now a staunch conservative, Mikhail Leont'ev (2005), recalls a "natural" transformation of his own and his generation's belief system: "The circle of people that I belonged to perceived the events of the beginning of the 1990s as a triumph of liberalism. I am ashamed of this. ...The Russian Soviet intelligentsia did the same thing in 1991 that it did in 1917" (pp. 67-68).

Contemporary public intellectuals support not the defense of human rights and individual liberties, but Russia's acquisition of great power status, its economic stabilization and the cementing of the transition achieved during the El'tsin era. The national interest has become of chief importance to many public intellectuals, whereby other values wane in comparison to Russia's desire to become a strong state and occupy its rightful place in world politics. No longer interested in the promotion of universal values of human rights and social justice, the intelligentsia emphasizes Russia's samobytnost' (particularity). Public intellectuals consider it absurd to care about such abstract categories as human rights and justice amidst the violence, corruption, and paucity of life that surrounds them, and when a large component of the intelligentsia itself is impoverished and humiliated by the loss of its social status during the 1990s. Increasingly adhering to an essentialistic, deterministic notion of culture as a static, "organic" given, many intellectuals breed

\footnotetext{
$\overline{20}$ Pavlovskii cited in Kagarlitsky (2002, pp. 126-128).

21 During the early stages of perestrojka, Migranjan already advocated a "strong hand" theory and "a more dictatorial approach to democracy" and even coined the term "demokratura". See Migranjan, Kliamkin (1990); Najshul' (1992).
} 
cultural particularism and refute the notion of the universal "end of history" by presenting Russian and Western "civilizations" as mutually impermeable entities, each following its own path of development. Reduced to this essentialistic cultural core, these intellectuals argue that civilizations do not choose their path of development, as their destiny is predetermined. In these civilizationist and culturalist accounts history gives way to Ersatz-history, a counterfeit constructed with the help of old stereotypes and new myths based on the binary opposition of Russian and Western "civilizations," each endowed with a set of traditions and nonmalleable values determined by unalterable cultural codes. These culturally relativistic accounts draw an impermeable mental border between Western and Russian "civilizations," whereby the West assumes once again the role of the Other against which Russian "differentness" is highlighted and Russian national identity is constructed and measured.

The transformation of many former pro-Western liberals among intellectuals into conservatives, and of dissenters into passive by-standers is linked to the perception of the failures of the fathers, the generation of intellectuals active during perestrojka. The morally spent force of Russia's young democracy was correlated in the eyes of many with the ethical failure of the conscience of the nation exemplified by shestidesjatniki's role during perestrojka and the first El'tsin years. No longer knights of liberalization on white horses shestidesjatniki are viewed by the younger generations as Don Quixotes of a lost cause. While some shestidesjatniki survived until the Putin era, and some of them even continue their intellectual and political activity today, the vast majority has found itself outside current political games. Shestidesjatniki's experience of democratic opposition is at best ignored, at worst serves as a reason to blame these intellectuals for the disastrous consequences of reforms and the intelligentsia's present ineptness. The memory of their deeds has sunk into oblivion and does not represent an example to follow for the young generation who are either apolitical or servile to the state.

Some shestidesjatniki are nostalgic for the last era of opposition and political activity during perestrojka. Thus, Jurij Burtin pondered before his death how "[o]ur intelligentsia is now on the surface, now disappears" (Burtin 2000, p. 181). The former 1960s dissident, who was one of the inspirational figures behind Gorbachev's reforms, published his A Confession of a Shestidesiatnik in Novyj mir, a journal that is still somewhat nostalgic of the era of shestidesiatnichestvo. While open to reminiscences about the intelligentsia's glorious past, the once highly politicized publication has become increasingly apolitical during Putin's administration. In a similar vein, the editors of Novaja junost', a new journal that was founded on the example of the notorious Junost', a mouthpiece of shestidesjatniki that first published Vasilij Aksjonov's early novels, let their readers know that their goal is "to stay away from the questions of ideology, politics, economics, law, national, and religious relations." 22 In the same issue, Valerja Novodvorskaja published "Shestidesjatniki i pustota" ("Shestidesjatniki and the Void"), in which she mocked 'thick journals' as "a sweet fruit of the bitter Russian roots, the roots of

$\overline{22}$ Novaia Iunost', Vol. 34, No. 1, 1999, p. 4. 
a lack of possessions, and, therefore, of idleness" (1999, p. 4). This was an epitaph to the generation.

Shestidesjatniki contributed to their own oblivion, and to the renunciation of their past which they enshrined as "melancholy, cries, and snot" (Novodvorskaja 1999, p. 4). In a way, by supporting the neo-liberal reforms of the early 1990s, whose economic ramifications eventually destroyed them, shestidesjatniki dug their own grave. In a dismal analysis of his generation, 85-year-old Granin announced that "there is nothing left from my generation," and with regard to the younger cohort of intellectuals he wrote: "[t]here are epochs and periods of a particular cynicism in life-when one lies not even in order to survive, but to amass a fortune, or out of pure fashion. It was easier to reach one's soul during the time of Gorbachev"(2005). With shestidesjatniki's disappearance from the political scene, the intelligentsia was indeed replaced by Western-type intellectuals.

It needs to be noted that while old age and a changed sociopolitical environment have greatly diminished the role of the surviving former dissidents and shestidesjatniki, many of them stayed true to liberal democratic ideals. Some of the perestrojka activists continue to be engaged through their work in charity and civic foundations, such as the Likhachev Foundation and the Gorbachev Foundation, but also in human rights work. Their present deeds, however, do not represent a viable and able political opposition, as before. Thus, Granin bemoaned the tragic death of a consolidated democratic movement as "the people that I respectChubajs, Khakamada, Javlinskij, Lukin-could not reach a consensus because of their ambitions and thus ruined the possibility of participation in parliamentary politics. This is unforgivable" (2005). The Congress of the Intelligentsia met for the last time in 2003. According to the director of the Moscow Bureau for Human Rights, Aleksandr Brod, the Congress' main discussion revolved around the issue of protest about the situation of "managed democracy, unprecedented centralization of power, and its further separation from the rest of society" (2003). The organizers of the congress pointed out that the intelligentsia is collaborating with the government instead of being concerned with the construction of civil society. While in today's Russia there are plenty of initiatives such as the Congress that are critical of the state of civil society, most end in pure rhetoric rather than in direct action.

New intellectuals are either disassociated from the concept of old-style intelligentsia, and are politically apathetic, or aim to become the regime's official spin doctors. In their criticism of the West and keenness for the Russian president, these intellectuals seem to forget that under Putin their country met its old ghosts and the intelligentsia's old nemesis: state control of information and ideational space, as well as the suppression of dissent. However, while the contemporary intelligentsia's passivity is one of the reasons for the lack of a viable opposition, another significant problem lies outside the group. The state does not permit even the faintest attempts at alternative political action to enter into the official political space. As Pavlovskij asserted to fellow members of the intelligentsia,

"(...) while the opposition is not transparent, it needs to be filtered... the acquisition of power by opposition that is politically non-transparent, 
intellectually incompetent, and financed by nobody knows who is impermissible...It is unlikely that the state will change its strategy of control." 23

Thus, a formerly active oppositionist now speaks of the lustratsija (the cleansing) of the opposition (Pavlovskij 2005). Migranjan similarly notes that without a "responsible" opposition the "attack" on the current government from those who disagree would lead to dire consequences. It has also become fashionable to warn of the dangers of another non-violent revolution like those in Georgia and Ukraine possibly happening in Russia. This, according to Migranjan, will lead to a complete disintegration of the country (Migranjan 2005).

In his reply to Pavlovskij, the former human rights activist in the civic organization Memorial, Aleksandr Daniel, rightly argued that there could be no opposition if the state imposes heavy control over the transparent and open information space where dialogue between the state and the people can take place. I need not repeat a well-known fact that the media in Russia are state-controlled, and apart from re-nationalized television few open outlets remain. The state leaves virtually no room for the opposition to grow and to reach the public. It marginalizes those members of the intelligentsia who disagree with official discourse. The example of Anna Politkovskaja and other journalists who openly protested the war in Chechnya and who seemingly perished as a result is a sad example of a more general trend that is reminiscent of the repressions of the Soviet era.

\section{Conclusion}

The last 20 years in the history of the Russian intelligentsia have been a period of great expectations and somber awakenings. During this time, the intelligentsia has come full circle in both its words and deeds. On the level of ideas, the liberal democracy discourse of the perestrojka years was supplanted by the disillusionment of the El'tsin era, which, in its turn, gave way to an antithetical set of conservative ideas. The generation of the fathers, once called "interior emigrants" (Likhachev 1996, p. 9) and "superfluous men" (Kagarlitsky 1988, p. 15), gave way to a generation of sons, who, characterized as Western-style intellectuals, became spin doctors and political technologists and replaced the original ideals and high moral stance of their predecessors with nihilistic nonchalance. Action-wise, intelligenty moved from the initial excitement over the crumbling of the Soviet regime and over the beginning of the long-awaited period of liberalization, to the realization that the road to democracy is tainted with difficulties and that it does not necessarily lead to freedom but to anarchy and a new form of authoritarianism instead. Thus, the initial joy turned into the uncertainty of the El'tsin years and eventually gave way to the loss of political energy and a new system of coordinates within the newly controlled ideational and political space of Putin's Russia.

Much of the intelligentsia transformed from being the altruistic conscience of Russia to becoming technicians of practical knowledge, polittekhnologi, who

${ }^{23}$ Pavlovskii (2005). 
employ their newly discovered craft of political persuasion to serve the state and advance its official ideology. The members of this new breed of intellectuals are no longer producers of authentic meanings and bottom-up messaging but managers of information delivered from above. For them, political ideas and ideals matter to the extent that they can become pieces of the puzzle of the national idea. Within this changed world of the intellectuals, politics is free of a moral dimension and serves as a tool for the attainment of social (and material) advancement. Many contemporary Russian intellectuals no longer hold freedom as their guiding principle, as freedom has become an abstract slogan with no meaning. These intellectuals are professionals who do not have the time, or the desire, to question the increasingly authoritarian regime in post-perestrojka Russia. Nor do they formulate and share any meaningful recipes for a better organized society.

The history of the Russian intelligentsia has come full circle in that its tragedy has repeated itself. The causal interrelationship between the intelligentsia's thoughts and actions on the one hand (manifested in the link between the shift from support of liberal democracy to the embracement of conservatism, and from political activism to passivity), and between the negatively-perceived example of the shestidesjatniki and the consent and apathy of the younger generations of intellectuals, fits within a century and a half of history of the Russian intelligentsia marked by highs and lows. As this paper illustrates, it is the perceived breach of the intelligentsia's tradition as the critic of the state that, together with other reasons, accounts for the current condition of Russian intellectualism. The words of Leon Trotsky therefore turned out to be prophetic: "[n]o matter how important was the significance of the intelligentsia, in the future its role will be reduced to that of servility and subjugation." 24 If one is optimistic, this period of passivity will give way to a new resurgence of dissent. This new wave of dissent might even make a difference.

Acknowledgements This article draws on a paper that was presented at the 7th Aleksanteri Conference, on 30 November, 2007 (Helsinki, Finland) which is based on earlier research at the Graduate Institute of International and Development Studies (University of Geneva, Switzerland). I would like to thank the Académie Suisse des sciences humaines et sociales (Bern, Switzerland) for the travel grant that made my attendance at the Aleksanteri Conference possible. I am also very grateful to Dr. André Liebich for all his invaluable comments throughout this project.

\section{References}

Adamovic, A. (1995). But where is the tsar? In Isham, H. (Ed.), Remaking Russia (pp. 91-107). New York: M.E. Sharpe.

Afanas'ev, Iu. (2005, January 31). Res publica. Vlast' kak tsel' i sredstvo. Svobodnaia Mysl' - XXI. Akhiezer, A. (1993). Rossiiskii liberalizm pered litsom krizisa. Obshchestvennye nauki i sovremennost, 1, $12-21$.

Burtin, Iu. (2000). Na poroge novykh dnei. Novyi Mir, 1.

Erofeev, V. (2004, March 15). Rossia i pustota Putina. Die Welt. Transl. and reprinted in http://www. inosmi.ru/translation/208430.html. Cited 25 December, 2007.

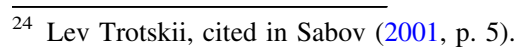


Fish, S. (1995). Democracy from scratch: Opposition and regime in the New Russian Revolution. Princeton: Princeton University Press.

Furedi, F. (2004). Where have all the intellectuals gone? Confronting 21st century conformism. London: Continuum.

Garcelon, M. (1997). The estate of change: The specialist rebellion and the democratic movement in Moscow, 1989-1991. Theory and Society, 26(1), 39-85.

Gasparov, M. (1999). Intellektualy, intelligenty, intelligentnost'. In Russkaia intelligentsiia: istoriia $i$ sud'ba. Moskva: Nauka.

German, T. (2003). Russia's Chechen war. London: Routledge Curzon.

Gessen, M. (1997). Dead again: The Russian intelligentsia after communism. London: Verso.

Granin, D. (1995). New dangers, new hopes. In H. Isham (Ed.), Remaking Russia (pp. 67-79). New York: M.E. Sharpe.

Granin, D. (1997, May 11). Russkii intelligent ukhodit. Izvestiia.

Granin, D. (2005, 12 August). Ot moego vremeni nichego ne ostalos'. Izvestiia Nauki. http://www. inauka.ru/philology/article38235.html. Cited 7 November, 2007.

Gudkov, L. (1992). Intelligenty i intellektualy. Znamia, 5.

Horvath, R. (2005). The legacy of Soviet dissent. Dissidents, democratisation and radical nationalism in Russia. London: RoutledgeCurzon.

Huskey, E. (2001). Democracy and institutional design in Russia. In A. Brown (Ed.), Contemporary Russian politics: A reader (pp. 29-45). Oxford: Oxford University Press.

Iur'ev, M. ([2004] 2005). Krepost' Rossiia. Proshchanie s liberalizmom. In M. Leont'ev, M. Iur'ev, M. Khazin, \& A. Utkin (pp. 14-73). Moskva: Eksmo.

Kagarlitsky, B. (1988). The thinking reed: Intellectuals and the state, 1917 to the present. London: Verso.

Kagarlitsky, B. (2002). Russia under El'tsin and Putin: Neo-liberal autocracy. London: Pluto Press.

Kolesnikov, A. (2004). Konservatism v salonakh i v bol'shoi politike. Vzgliad liberala. Beseda s Andreem Kolesnikovym. Neprikosnovennyi Zapas, 5 (37). http://www.nz-online.ru/index.phtml?aid=25011158. Cited 10 November 2007.

Kotkin, S. (1995). Magnetic mountain: Stalinism as a civilization. Berkeley: University of California Press.

Kuzman, C., \& Owens, L. (2002). Sociology of intellectuals. Annual Review of Sociology, 28, 63-90.

Laufer, L., \& Bengston, V. (1974). Generations, aging and social stratification: On the development of generational units. Journal of Social Issues, 30(3), 181-205.

Leont'ev, M. (2005, September 30). Interv'iu nomera: Mikhail Leont'ev: Putinu trudno preodolet' liberal'nyi totalitarizm. Politicheskii klass.

Lieven, A. (1999). Chechnya: Tombstone of Russian power. New Haven: Yale University Press.

Likhachev, D. (1996). Sud'ba rossiiskoi intelligentsii: materialy nauchnoi diskussii, 23 maya 1996. Sankt-Peterbourg: Sankt Peterbourgskii Gumanitarnyi Universitet.

Mannheim, K. ([1927] 1952). The problem of generations. In P. Kecskemeti (Ed.), Essays on the sociology of knowledge (pp. 276-320). London: Routledge \& Kegan Paul.

Medvedev, R. (2004). Vladimir Putin: Chetyre Goda v Kremle. Moskva: Vremia.

Memetov, V. (1996). K pervym itogam stanovleniia "intelligentovedeniia" kak samostoiatelnoi oblasti nauchnogo znaniia. In V. Memetov (Ed.), Aktualnye problemy istoriografii otechestvennoi intelligentsii: Mezhvuzovskii respublikanskii sbornik nauchnykh trudov. Ivanovo: Ivanovskii gosudarstvennyi universitet.

Mezhuev, B. (2004, June 17). Konservatizm i traditsionalizm. Otlichiia. Novaia politika. http://www. novopol.ru. Cited 8 November, 2007.

Migranjan, A. (2005, March 30). Antiputinskaia koalitsiia opasna ne dlia Putina, a dlia Rossii: nasha oranzhevaia revolutsiia mozhet byt' krasno-korichnevogo ili zelenogo tsveta. Politicheskii klass. http://www.politklass.ru/cgi-bin/issue.pl?id=69. Cited 3 November, 2007.

Migranjan, A., \& Klyamkin, I. (Eds.). (1990). Sotsializm i demokratiia: Diskussionnaia tribuna. Moskva.

Najshul, V. (1992). Liberalizm i ekonomicheskie reformy. Mirovaia Ekonomika $i$ Mezhdunarodnye otnosheniia, 8 .

Neklessa, A. (2005, 3 March). Novyi intellektual'nyi klass Public Lecture at Bilingua. http://www. polit.ru/lectures/2005/03/15/neklessa.html. Cited 10 November, 2007.

Nikolaeva, I. (1997, September 18). Pozitsiia: XX vek bez intelligentsii? Rossiiskie vesti.

Novodvorskaia, V. (1999). Shestidesjatniki i pustota. Novaia Iunost', 1 (34). http://magazines.russ.ru/ nov/_yun/1999/1/novodvor.html. Cited 10 November, 2007. 
Pavlovskii, G. (2005, 10 February). Vlast' i oppozitsiia: kriterii effektivnosti. Public Lecture at Bilingua. http://www.polit.ru/lectures/2005/02/18/pavl.html. Cited 8 November, 2007.

Pelevin, V. (1999). Generation P. Moscow. Vagrius.

Pelevin, V. (2003, September 2). Istoriia Rossii-eto prosto istoria mody. Gazeta.ru. http://pelevin.nov.ru/ interview/o-gaz/1.html. Cited 25 December, 2007.

Petro, N. (1991). Perestrojka from Below: Voluntary sociopolitical associations in the RSFSR. In A. Rieber \& A. Rubinstein (Eds.), Perestrojka at the crossroads. New York: M.E.Sharpe.

Poliakov, V. (2000, February 2). Liberal'nyi konservator. Nezavisimaia Gazeta.

Popov, G. (2003, October 15). Bloody October. Argumenty i Fakty.

Putin, V. (2000). Russia at the Turn of the Millenium. 1999 Policy Manifesto. http://www.pravitelstvo. gov.ru. Cited 16 October, 2007.

Riazanov, E. (1992, January 28). Vremia maroderov. Nezavisimaia Gazeta.

Sabov, A. (2001, March 14). V samom li dele nastupil konets intelligentsii? Rossiiskaia Gazeta. http://www.rg.ru/Anons/arc_2001/0314/hit.shtm. Cited Nov 25, 2007.

Sartre, J.-P. ([1965] 1972). Plaidoyer pour les intellectuels. Paris: Gallimard.

Sheinis, V. (2003). U istokov novogo parlamentarizma v Rossii. Obshchestvennye nauki i sovremennost', 3, 31-44.

Shils, E. (1969). The intellectuals and the powers: Some perspectives for comparative analysis. In A. Author (Ed.), On intellectuals: Theoretical studies, case studies. New York: Doubleday \& Company, Inc.

Smolina, V. (2000). Russkaia intelligentsia v postkommunisticheskoi epokhe. In Fenomen rossiiskoi intelligentsii: istoriia i psikhologiia. Materialy mezhdunarodnoi nauchnoi konferentsii, 24-25 maia. Sankt-Peterbourg: Nestor.

Surkov, V. (2006, March 10). Suverenitet eto politicheskii sinonim konkurentosposobnosti," Moskovskie novosti. http://www.mn.ru/issue.php?2006-8-1. Cited 1 November, 2007.

Tret'iakov, V. (1997, November 14). A est' li mal'chik? Nezavisimaia Gazeta.

Voronkov, V. (2005). Proekt 'shestidesiatnikov': dvizhenie protesta v SSSR. In Iu. Levada \& T. Shanin (Eds.), Otsy i deti. Pokolencheskii analiz sovremennoi Rossii (pp. 168-201). Moksva: Novoe Literaturnoe Obozrenie.

Zalygin, S. (1995, January 18). Bremia derzhavnosti razdavit Rossiiu. Izvestiia.

Zaslavskaia, T. (1988). O strategii sotsial'nogo upravleniia perestroikoy. In Iu. Afanasiev (Ed.), Inogo ne dano: Sud'by perestroiki: Vgliadyvaias' $v$ proshloe, vozvrashchenie $k$ budushchemu. Moskva: Progress.

(1989). The Democratic Union Program. Archive of the Democratic Union, 1989. http://www.ds.ru/ oldprog.htm. Cited 2 October, 2007.

(1993, December 19). Declaration of the Democratic Union of Russia. http://www.ds.ru/ust.htm. Cited 3 October, 2007. 